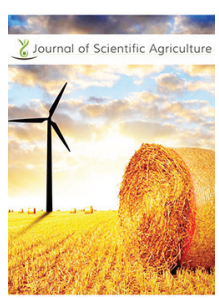

ISSN: $2184-0261$

\title{
The effect of lysine supplementation on the performance of Myanmar local breed and DYL crossed breed pig
}

\author{
Sai Koung Ngeun ${ }^{1 *}$, Khin Hnin Swe², Aye Aye Maw³, Hla Hla Moe \\ 'Livestock Breeding and Veterinary Department, Hsipaw Township, Shan State, Myanmar, ${ }^{2}$ Department of Animal \\ Science, University of Veterinary Science, Yezin, Nay Pyi Taw, Myanmar, ${ }^{3}$ Department of Genetics and Animal \\ Breeding, University of Veterinary Science, Yezin, Nay Pyi Taw, Myanmar
}

\begin{abstract}
A Completely Randomized Design (CRD) was comprised 2x3 factorial arrangements of two breeds (DYL and local breed) and three different lysine levels. The 18 weeks old, nine castrated DYL and nine local breed were randomly allocated in each individual pen to six treatment groups with three replicates into 18 pens. Two breeds of pigs (DYL and local breed) were exposed to the three different dietary treatments, Ll- basal diet without lysine supplementation, L2- basal diet with $0.95 \%$ total lysine for finisher and L3- basal diet with $1.45 \%$ total lysine for finisher. The growth performance and back fat thickness were determined for finishing pigs. Significantly better body weight, weight gain, feed conversion ratio (FCR) and lower back fat were observed in pigs fed L2 but did not significantly differ from those fed L3. Otherwise, diets without lysine supplementation ( $\mathrm{Ll}$ ) showed no better effect on the growth performances of both DYL and local breeds. It could be noted that L2 was the best level to obtain optimal growth performances and feed efficiency. Between the two breeds, growth performances of DYL were superior over that of local breed. Back fat thicknesses of DYL were also thinner than that of local breed. The interactions were observed between lysine levels and different breeds regard for final body weight, cumulative gain and feed conversion ratio. It was noticeable that lysine supplementation helped to improve growth performance and reduce back fat thickness of both local breed and DYL crossed breed. The result also showed that a comparison of the two different breed revealed the improved performances in DYL crossed breed rather than that of local breed.
\end{abstract}

*Corresponding Author:

Sai Koung Ngeun

Email: saikoungngeun@gmail.com KEYWORDS: Lysine, local breed, DYL crossed breed, growth performance, back fat thickness, interaction

\section{INTRODUCTION}

In Myanmar, the livestock production is dominated by indigenous breeds and raised by traditional method. The Myanmar native pigs are characterized by thick fat, hardiness and poor growth, weighs about $60 \mathrm{~kg}$ only at one year of age. So, the indigenous breed grows more slowly than the exotic cross breeds. The general characteristics of Myanmar local breeds have small and moderately dished head, concave back and pendulous belly. [1].

Purebred native genotypes have lower growth performances than European pigs and thus are unsuitable for commercial production. Exotic breeds of pigs have higher feed conversion efficiency and faster growth rate and have higher growth potential than indigenous breeds [2]. Korean Native Pig also have slower growth rate and higher fat than commercial cross breed of Landrace $\times$ Yorkshire $\times$ Duroc (DYL) [3].
Furthermore, inadequate nutrition and feeding seem to be the major factors for low production performance [4]. Because of proteins and amino acids play a crucial role in the formulation of swine ration, feeding a diet containing less protein may result in somewhat poorer performance due to the lack of sufficient lysine. They are also essential for the normal growth of body tissues, synthesis of macromolecules involved in structural, metabolic and functional activities, reproduction and disease resistance of animals [5].

In corn-soybean meal diet for pigs, lysine is the first limiting amino acid and methionine is the second limiting amino acid. Because of the concentration of lysine in pork is relatively high (about 7\%) and the feedstuffs commonly fed to pigs are quite low in lysine, it is the first limiting amino acid for pig. [6].

Supplementation of the lysine, most limiting amino acid, may affect both voluntary feed intake and efficiency of dietary energy utilization and consequently production performance $[7,8]$

Copyright: $\odot 2018$ The authors. This article is open access and licensed under the terms of the Creative Commons Attribution License (http://creativecommons.org/licenses/by/4.0/) which permits unrestricted, use, distribution and reproduction in any medium, or format for any purpose, even commercially provided the work is properly cited. Attribution - You must give appropriate credit, provide a link to the license, and indicate if changes were made. 
Moreover, finishing barrows that are fed lysine supplemented diet can be achieved improved performances including ADG, FCR, carcass weight and grade [9]. The supplementation of lysine also influence on the gene expression and dietary utilization of nutrient [10].

As lysine is the first limiting amino acid in the diet of pig, the research work concerned with lysine supplementation is needed. The effect of lysine supplementation on the performance of DYL and local breed has not been investigated yet in Myanmar. Therefore, the aim of this study was to evaluate the effect of lysine supplementation at different levels in the diet on the growth performance of two different breeds of pigs.

\section{MATERIALS AND METHODS}

\section{Experimental animals}

Nine DYL [(Landrace $\times$ Yorkshire $) \times$ Duroc] castrated male crossed breed and nine local breed castrated male, 18 weeks old pigs were used in this experiment. Before feeding the experimental diets, all pigs were de-wormed and vaccinated with Hog Cholera vaccine. Initial weights of the pig were recorded individually.

\section{Preparation of experimental diet}

Compositions of the experimental diet and nutrient levels are shown in Table 1. The experimental diets were included; diet 1: basal diet only without lysine supplementation, diet 2: basal diet with total lysine of $0.95 \%$ for finisher and diet 3: basal diet with total lysine of $1.45 \%$ for finisher. Each diet was provided as dry form and two times per day at 9:00 am and 3:00 pm. Feed given and refusals were recorded daily to measure feed intake. Water was provided ad libitum throughout the experimental period.

\section{METHODS}

\section{Experimental design}

Completely randomized design (CRD) was used. There were six treatments comprising a $2 \times 3$ factorial arrangement of two different breeds (local breed and DYL) and three diets with or without lysine supplementation. Each treatment replicate three times, with one castrated male pig constituting a replicate. All

Table 1: Composition of experimental diets

\begin{tabular}{lccc}
\hline Ingredients & Diet 1 \% & Diet 2\% & Diet 3\% \\
\hline Corn & 49.00 & 49.00 & 52.60 \\
Rice Bran & 12.00 & 12.00 & 10.00 \\
Broken Rice & 20.00 & 20.00 & 18.00 \\
Soybean Meal & 15.00 & 15.00 & 15.00 \\
Fish & 3.00 & 3.00 & 3.00 \\
Lysine & - & 0.14 & 0.65 \\
Premix & 1.00 & 0.86 & 0.75 \\
Total & 100.00 & 100.00 & 100.00 \\
CP \% & 16.00 & 16.00 & 16.00 \\
ME (Kcal/kg) & 3265.00 & 3265.00 & 3265.00 \\
Lysine \% & 0.81 & 0.95 & 1.45 \\
\hline
\end{tabular}

J Sci Agric • 2018 - Vol 2 pigs were randomly allocated in each individual pen. The pigs were kept in the cages for one week to acclimatize the conditions before data collections begin.

\section{Measurement and analysis}

\section{Growth performance and feed conversion ratio}

Animals were weighed at the beginning and weekly throughout the experimental period and recorded. The feed intake per pen was recorded daily throughout the experimental period and each pig was weighed at the beginning and the end of the experiment to determine weight gain and feed conversion ratios.

\section{Statistical analysis}

All data collected in this study were analysed by using analysis of variance (ANOVA, SAS ${ }^{\circledR}$ Institute, 2002). The differences among treatment groups were examined by Duncan's Multiple Range Test (DMRT).

\section{RESULT}

Main effects of lysine supplementations and breeds on performance of pigs

The main effects of lysine supplementation and breed on performance of pigs are shown in Table 2. The body weight $(\mathrm{kg})$ and cumulative gain $(\mathrm{kg})$ of pigs treated with L2 was the highest and pig treated with Ll was the lowest. The body weight $(\mathrm{kg})$ and cumulative gain $(\mathrm{kg})$ of pigs treated with L2 was not significantly different from that of groups treated with L3 but was significantly higher $(\mathrm{p}<0.001)$ than that of group treated with Ll. The body weight $(\mathrm{kg})$ and cumulative gain $(\mathrm{kg})$ of DYL was significantly higher $(\mathrm{p}<0.001)$ than that of local breed.

The feed conversion ratio (FCR) of pigs treated with L2 was the narrowest and pig treated with Ll was the widest. The feed conversion ratio (FCR) of pigs treated with L2 not significantly different from that of groups treated with L3 but was significantly narrower $(\mathrm{p}<0.001)$ than that of group treated with Ll. The feed conversion ratio (FCR) of DYL was significantly narrower $(\mathrm{p}<0.001)$ than that of local breed.

The back fat thickness (mm) (BFT) of pigs treated with Ll was the highest and pig treated with $\mathrm{L} 2$ was the lowest. The back fat thickness (mm) (BFT) of pigs treated with L2 was not significantly different from pig treated with $\mathrm{L} 3$ but was significantly thinner $(\mathrm{p}<0.05)$ than that of group treated with Ll. The back fat thickness (mm) (BFT) of DYL was significantly thinner $(\mathrm{p}<0.05)$ than that of local breed.

There were no interactions $(p<0.05)$ between lysine and breed in back fat thickness (mm) (BFT) of pigs in the overall experimental period. Significant interactions between lysine and breed at $(\mathrm{p}<0.05)$ were found in body weight $(\mathrm{kg})$, feed conversion ratio FCR and cumulative weight gain $(\mathrm{kg})$ of pigs in the overall experimental period. 
The effects of different lysine levels and breeds on the performance of pigs

The effects of different lysine levels and breeds on the performance of pigs are shown in Table 3. The final body weight $(\mathrm{kg})$ and cumulative weight gain $(\mathrm{kg})$ of pigs treated with T3 was the highest and pigs treated with T2 was the lowest. The feed conversion ratio (FCR) of pigs treated with T3 was narrowest and pigs treated with $\mathrm{T} 2$ were the widest. The back fat thickness (mm) (BFT) of pigs treated with $\mathrm{T} 2$ was the highest and pigs treated with $\mathrm{T} 5$ were the lowest. To wrap up, the pigs treated with T3 and T5 had the highest performance and the pigs treated with $\mathrm{T} 2$ had the lowest performance.

\section{DISCUSSION}

\section{Growth Performances}

In this study, supplementation of crystalline lysine to basal diets, formulated to $0.95 \%$ (L2), increased body weight, cumulative gain and improvement in FCR of pigs. Increasing lysine levels to $1.45 \%$ (L3) also resulted in increased body weight, cumulative gain and improvement in FCR of pigs. Although numerical means favoured the highest lysine levels (L3), the effects were not significantly different from the mean values for (L2). Possibly, the lysine concentration of L2 was sufficient for optimal growth performance. Therefore, it could be defined that L2 was the appropriate level to gain the optimal performances. The basal diet without lysine supplementation, lowest level of lysine (L1), in this experiment seems to have no effect on the performances of both breeds.

Results similar to current findings have been reported previously that reduction of growth performance in pigs might be expected as lysine concentration decreased in the diet [11]. Other authors also observed improved performance as dietary lysine level increases [12-14]. When the lysine to energy ratio increased average daily weight gain increased in growing finishing pigs $[15,16]$. The finisher pigs that were fed with the high amino acid diet tended to grow faster and better feed conversion than those offered in low amino acid diet [17]. Increasing dietary lysine improved gain:feed ratio in finishing pigs [18]. This might be due to lysine supplementation increased the nitrogen retention and protein accretion, and improved the growth performance of the animals.

In contrast, growth performances of pigs were not affected by increasing level of lysine and ME [19]. Similarly, feed conversion ratio was not influenced by an increased level of lysine [20]. During growing and fattening stage of production, lysine levels can be reduced safely by $15 \%$ in diet compared to that of NRC (1998) without compromising on performance of pig [21].

Lysine is a key amino acid that animals need to optimize their genetic potential. In the aspects of breed, DYL were superior to that of Myanmar local breed regard for parameters measured in the current experiment. The growth performance was significantly affected by breed [22]. Farm efficiency and production performance could be improved by production of crossbred pigs [23]. The genetic improved pig breeds had better growth performance than Myanmar local breed. Genetically high crossed breed have more growth potential than Myanmar local breed that grew $60 \mathrm{~kg}$ only at one year of age [24]. Korean native pig showed slower growth rate and lighter carcass weight than commercial pig breed (DYL) and had more great production efficiency than pure or two-way crossbreds [25]. This means improved farm efficiency could be obtain by producing of crossed breed pigs.

In the current study, the lysine $\times$ breed interaction was significant for body weight, cumulative gain and FCR. The response of pigs to addition of lysine was not similar when the breed is different. The response of DYL to additional

Table 2: Main effects of lysine supplementation and breed on performance of pigs

\begin{tabular}{|c|c|c|c|c|c|c|c|c|}
\hline \multirow[t]{2}{*}{ Parameters } & \multicolumn{3}{|c|}{ Lysine supplementations } & \multirow[t]{2}{*}{ Sig. level } & \multicolumn{2}{|c|}{ Breeds } & \multirow[t]{2}{*}{ Sig. level } & \multirow[t]{2}{*}{ Lys $\times$ Breed } \\
\hline & $\mathrm{Ll}$ & $\mathrm{L} 2$ & $\mathrm{~L} 3$ & & Local & DYL & & \\
\hline Body weight $(\mathrm{kg})$ & $92.50 \pm 3.06^{b}$ & $98.22 \pm 2.80^{a}$ & $97.67 \pm 2.24^{\mathrm{a}}$ & $* *$ & $90.11 \pm 1.13^{b}$ & $102.14 \pm 0.76^{a}$ & $* *$ & * \\
\hline Cumulative weight gain $(\mathrm{kg})$ & $35.70 \pm 2.27^{b}$ & $39.54 \pm 2.06^{a}$ & $39.03 \pm 1.41^{\mathrm{a}}$ & $* *$ & $33.39 \pm 0.87^{b}$ & $42.29 \pm 0.54^{a}$ & $* *$ & * \\
\hline Feed conversion ratio & $4.46 \pm 0.28^{a}$ & $4.00 \pm 0.21^{b}$ & $4.03 \pm 0.15^{b}$ & $* *$ & $4.63 \pm 0.12^{\mathrm{a}}$ & $3.70 \pm 0.05^{b}$ & $* *$ & * \\
\hline Back fat thickness (mm) & $16.83 \pm 0.60^{\mathrm{a}}$ & $15.17 \pm 0.31^{\mathrm{b}}$ & $15.67 \pm 0.71^{\mathrm{b}}$ & * & $16.89 \pm 0.42^{\mathrm{a}}$ & $14.89 \pm 0.31^{b}$ & * & NS \\
\hline
\end{tabular}

$a, b$ The means with different superscripts within the same row are significantly different at $(p<0.001)^{* *}$ and $(p<0.05) *$. NS $=$ non-significant, $L 1=$ without lysine supplementation, $L 2=$ total lysine of $0.95 \%$ for the finisher, $L 3=$ total lysine of $1.45 \%$ for the finisher

Table 3: The effects of different lysine levels and breeds on the performance of pigs

\begin{tabular}{|c|c|c|c|c|c|c|c|}
\hline \multirow[t]{2}{*}{ Parameters } & \multicolumn{6}{|c|}{ Treatments } & \multirow[t]{2}{*}{ Sig. level } \\
\hline & 1 & 2 & 3 & 4 & 5 & 6 & \\
\hline Body weight (kg) & $99.33 \pm 0.17^{c}$ & $85.67 \pm 0.33^{e}$ & $104.43 \pm 0.30^{a}$ & $92.00 \pm 0.58^{d}$ & $102.67 \pm 0.17^{b}$ & $92.67 \pm 0.18^{d}$ & $* *$ \\
\hline Cumulative weight gain $(\mathrm{kg})$ & $40.73 \pm 0.52^{b}$ & $30.67 \pm 0.33^{d}$ & $44.08 \pm 0.65^{a}$ & $35.00 \pm 0.38^{c}$ & $42.05 \pm 0.13^{b}$ & $36.00 \pm 0.91^{c}$ & $* *$ \\
\hline Feed conversion ratio & $3.83 \pm 0.05^{c}$ & $5.09 \pm 0.06^{a}$ & $3.54 \pm 0.05^{d}$ & $4.46 \pm 0.05^{b}$ & $3.71 \pm 0.01^{d}$ & $4.34 \pm 0.11^{b}$ & $* *$ \\
\hline Back fat thickness (mm) & $15.67 \pm 0.33^{b c}$ & $18.00 \pm 0.58^{\mathrm{a}}$ & $14.67 \pm 0.33^{c}$ & $15.67 \pm 0.33^{b c}$ & $14.33 \pm 0.67^{c}$ & $17.00 \pm 0.58^{a b}$ & * \\
\hline
\end{tabular}


lysine was greater than local breed. Therefore, it might be noted that the requirement of lysine could not be the same between different breed. It might be because of their different genetic potential and protein accretion rate. Some grower diet $\times$ genotype interactions were found and a diet containing adequate lysine and amino acid should be fed in order to optimize overall growth performance pigs selected for lean growth efficiency [26]. Although the dietary lysine was increased, the largest improvements in growth performance, carcass characteristics and protein accretion were detected regardless of genotype [27]. The interactions between diet and genotype were not observed [28].

\section{Back fat thickness}

The current results showed that pigs fed lowest lysine level (Ll) in the diet had higher back fat thickness than those fed L2 and L3. This might be because of feeding diets containing less than adequate lysine concentration affected the ability of the pigs to use energy for protein deposition.

The animals consumed feeds with higher lysine level had a trend towards increasing in gain, muscle of longgissimus dorsi and decreasing in back fat thickness [29]. The meat quality was also improves with increasing level of lysine content in diet [30, 31]. When the lysine to energy ratio was increased from 1.35 to $2.59 \mathrm{~g} \mathrm{Lys} / \mathrm{Mcal} \mathrm{DE}$, growth performance and carcass trait were improved but there is a concomitant reduction in marbling and back fat thickness [32]. However, dietary lysine level had no effect on average back fat at $55 \mathrm{~kg}$ body weight [33]. Conversely, average fat depth was increased with dietary energy-lysine level [34].

The data from the current study indicated that local breed had greater back fat thickness than DYL crossed breed. As a consequence of poor genetic capacity, higher lipid deposition can potentially account for the decreased ADG with the result that increased back fat in local breed than that of DYL crossed breed.

The variability of back fat may be due to the level of lysine, the genetic capacity for lean tissue retention [35]. Indigenous pigs of South East Asia are fattier compared to that of South Asian pigs [36]. Fat percent of Myanmar local breed is $11.8 \%$ and is greater than hybrid breed that have only $2 \%$ [37]. The lean meat content class, otherwise body fat percent, had relation with back fat thickness [38].

Improved farm efficiency could be obtained by producing of crossed breed pigs. Using Duroc boar in crossing with other breed also result in the production of best quality carcasses with correct ratios between lean and adipose cuts and have an impact on meat quality [39]. Duroc $\times$ (Landrace $\times$ Yorkshire) (DLY) had good carcass and meat quality traits than Chinese native crossbreeds [40]. However, differences between pure breeds and Cross-breeds in back fat were not significant [41].

\section{CONCLUSION}

According to the present findings, supplementation of lysine leads to have a beneficial effect on the growth performances and reduce back fat thickness of pigs. Beside the supplementation of lysine, DYL crossed breed showed better growth performance and lower back fat compared to that of Myanmar local breed. Therefore, it could be concluded that lysine supplementation in the pig diet is essential and could provide better performances in both different breeds.

\section{REFERENCES}

1. Kurosawa Y, Tanaka K, Yamagata T, Suzuki Y, Mannen H, Nishibori M, Nozawa K, Maeda Y, Nay Win, Than Hla, Than Daing and Maung Maung Nyunt. Morphological study on the external characteristics of Myanmar's native pig production. Rep. Soc.Res. Native Livestock, 2004. 21: 195-204

2. Mishra RR, Prasad S and Lal K. Studies on carcass traits of Large White Yorkshire pigs. Indian J. Anim. Prod. Mgmt, 1989. 5: 130-133.

3. Kim JH, Park BY, Yoo YM, Cho SH, Kim YK, Lee JM, Yun HJ and $\mathrm{Kim} \mathrm{KN}$. Ch aracteristics of carcass and meat yield of fattening pigs by production step. J. Anim. Sci \& Technol, 2002. 44: 793-800.

4. Mbuthia JM, Rewe TO and Alexander Kigunzu Kahi AK. Evaluation of pig production practices, constraints and opportunities for improvement in smallholder production systems in Kenya. Trop. Anim. Health Prod, 2015. 47: 369-376.

5. Kaur S, Mandal AB, Singh KB and Narayan R. Responses of growing Japanese quails (heavy body weight line) to graded levels of essential amino acid concentrations in diets with or without fishmeal. J. Sci. Food Agric, 2006. 86: 320-327.

6. Lewis AJ. Amino Acids in Swine Nutrition. In. Swine Nutrition. $2^{\text {nd }}$ ed. (Eds. Lewis AJ and Southern LL). CRC Press LLC, USA, 2001. p.141-150.

7. Fuller MF, Cadenhead A, Mollison A and Sève B. Effects of the amount and qurtlity of dietary protein on nitrogen metabolism and heat production in growing pigs. Br. J. Nutr, 1987. 58: 277.

8. Noblet J, Henry $Y$ and Dubois S. Effect of protein and lysine levels in the diet on body gain composition and energy utilization in growing pigs. J. Anim. Sci, 1987. 85: 717.

9. Cho SB, Han IK, Kim YY, Park SK, Hwang OH, Choi, Yang SH, Park KH, Choi DY and Yoo YH. Effect of lysine to digestible energy ratio on growth performance and carcass characteristics in finishing pigs. Asian-Aust. J. Anim. Sci, 2012. 25: 1582-1587.

10. Wang W, Gu W and Tang X. Molecular cloning, tissue distribution and ontogenetic expression of the amino acid transporter $b^{0,+}$ cDNA in the small intestine of Tibetan suckling piglets. Comp. Biochem. Physiol. B Biochem. Mol. Biol, 2009. 154: 157-164.

11. Rodríguez-Sánchez JA, Sanz MA, Blanco M, Serrano MP, Joy M and Latorre MA. The influence of dietary lysine restriction during the finishing period on growth performance and carcass, meat, and fat characteristics of barrows and gilts intended for dry-cured ham production. J. Anim. Sci, 2011. 89: 3651-3662.

12. De La Llata M, Dritz SS, Tokach MD, Goodband RD and Nelssen JL. Effects of Increasing Lysine to Calorie Ratio and Added Fat for Growing-Finishing Pigs Reared in a Commercial Environment: I. Growth Performance and Carcass Characteristics. Prof. Anim. Sci, 2007. 23: 417-428.

13. Davis ME, Rodas BZ, Maxwell CV and Chung J. Effect of Increasing Dietary Lysine Level with Addition of Whey Protein Concentrate on Pig Performance During Phase 1 of The Nursery Period, 1996.

14. Figueroa JL, Estrada J, Zamora V, Cordero JL, Sánchez-Torres MT, Nieto R and Copado JMF. Digestible lysine levels in low-protein diets supplemented with synthetic amino acids for nursery, growing, and finishing barrows. Irish Journal of Agricultural and Food Research, 2012. 51: 33-44.

15. Rao DS and McCracken KJ. Effect of protein intake on energy and nitrogen balance and chemical composition of gain in growing boars of high genetic potential. Anim. Prod, 1990. 51: 389-397.

16. Zhang GJ, Yi XW, Chu LC, Lu N, Htoo J and Qiao SY. Effects of Dietary Net Energy Density and Standardized Ileal Digestible Lysine: Net Energy Ratio on the Performance and Carcass Characteristic of Growing-Finishing Pigs Fed Low Crude Protein Supplemented with Crystalline Amino Acids Diets. Agric. Sci. China, 2011. 10: 602-610.

18. Witte DP, Ellis M, McKeith FK and Wilson ER. Effect of dietary lysine level and environmental temperature during the finishing 
phase on the intramuscular fat content of pork. J. Anim. Sci, 2000. 78: 1272-1276.

19. Otten C, Berk A and Dänicke S. Voluntary feed intake and growth performance of boars and barrows in dependence on lysine-toenergy ratio. Archiv Tierzucht, 2013. 56: 399-409.

20. Eggert JM, Farrand EJ, Schinckel AP and Mills SE. The Effects of Dietary Fat and Lysine on Pig Growth, Pork Quality and Carcass Composition. Purdue University. Swine Day Report, 1997.

21. Kumar A, Bhar R, Mandal AB and Mendiratta SK. Effect of low protein diets and lysine supplementation on growth performance and carcass characteristics of growing pigs. Afr. J. Biotechnol, 2012. 11: 12128-12134.

22. Renaudeau D, Giorgi M, Silou1 F and Weisbecker JL. Effect of Breed (Lean or Fat Pigs) and Sex on Performance and Feeding Behaviour of Group Housed Growing Pigs in a Tropical Climate. Asian-Aust. J. Anim. Sci, 2006. 19: 593-600.

23. Bennet GL, Tess WM, Dickerson GE and Johnson RK. Simulation of breed and crossbreeding effects on costs of pork production. J. Anim. Sci, 1983. 56: 801-803.

24. National Consultative Committee, Myanmar. National Report on Animal Genetic Resources, The Union of Myanmar, 2001.

25. Nelson RE and Robison OW. Comparisons of specific two and three way crosses of swine. J. Anim. Sci, 1976. 42: 1150-1157.

26. Chiba LI, Kuhlers DL, Frobish LT, Jungst SB, Huff Lonergan EJ, Lonergan SM and Cummins KA. Effect of dietary restrictions on growth performance and carcass quality of pigs selected for lean growth efficiency. Livest. Prod. Sci, 2002. 74: 93-102.

27. Friesen KG, Nelssen JL, Unruh JA, Goodband RD and Tokach MD. Effects of the interrelationship between genotype, sex, and dietary lysine on growth performance and carcass composition in finishing pigs fed to either 104 or 127 kilograms. J. Anim. Sci,1994. 72: 946-954.

28. Fabian J, Chiba LI, Kuhlers DL, Frobish LT, Nadarajah K, Kerth CR, McElhenney $\mathrm{WH}$ and Lewis AJ. Degree of amino acid restrictions during the grower phase and compensatory growth in pigs selected for lean growth efficiency J. Anim. Sci, 2002. 80: 2610-2618.

29. Petrov P. Testing of compound feeds containing different level of lysine in feeding fattening pigs. Bulg. J. Agric. Sci, 2006. 12: 823-829.

30. Loughmiller JA, Nelssen JL, Goodband RD, Tokach MD, Titgemeyer EC and Kim IH. Influence of dietary lysine on growth performance and carcass characteristics of late-finishing gilts. J. Anim. Sci, 1998. 76: 1075-1080.

31. Szabo C, Jansman AJ, Babinszky L, Kanis E and Verstegen MW.
Effect of dietaryprotein source and lysine: DE ratio on growth performance, meat quality and body composition of growingfinishing pigs. J. Anim. Sci, 2001. 79: 2857-2865.

32. Castell AG, Cliplef RL, Poste-Flynn LM and Butler G. Performance, carcass and pork characteristics of castrates and gilts self-fed diets differing in protein content and lysine: energy ratio. Can. J. Anim. Sci, 1994. 74: 519-528.

33. Friesen KG, Nelssen JL, Goodband RD, Tokach MD, Unruh JA Kropf DH and Kerr BJ. Influence of dietary lysine on growth and carcass composition of high-lean-growth gilts fed from 34 to 72 kilograms. J. Anim. Sci, 1994. 72: 1761-1770.

34. McPhee CP and Daniels LJ. Effects of genotype, diet and sex on back fat depth in pigs measured physically at different carcass sites and ultrasonically at different liveweights. Aust. J. Experi. Agri, 1991 31: 761-764.

35. Hansen BC and Lewis AJ. Effects of dietary protein concentration (corn: soybean meal ratio) on the performance and carcass characteristics of growing boars, barrows, and gilts: mathematical descriptions. J. Anim. Sci, 1993. 71: 2122-2132.

36. Deka RP, Grace D, Lapar ML, Lindahl J. Sharing Lessons of Smallholders' Pig System in South Asia and Southeast Asia: a Review. International Livestock Research Institute (ILRI). National Conference on Opportunities and strategies for Sustainable Pig Production organized by the ICAR-National Research Centre on Pig, Rani, Guwahati, India, 2014.

17. Chiba LI. Effects of dietary amino acid content between 20 and 50 and 50 and $100 \mathrm{~kg}$ live weight on the subsequent and overall growth performance of pigs. Livest. Prod. Sci, 1994. 39: 213-221.

37. FAO. Swine industry profile of selected South East Asian countries. Swine Industry Profile of Myanmar, 2011. p. 22-53.

38. Knecht D and Duzin-ski K. The effect of sex, carcass mass, back fat thickness and lean meat content on pork ham and loin characteristics. Arch. Anim. Breed, 2016. 59: 51- 57.

39. Sabbioni A, Superchi P, Sussi $C$ and Bonomi A. Effect of Duroc genes proportion on growth performance and on carcass and meat quality characteristics in heavy pigs. Ital. J. Anim. Sci, 2002. 1: 17-24.

40. Jiang $Y Z$, Zhu L, Tang GQ, Li MZ, Jiang AA, Cen WM, Xing SH, Chen JN, Wen AX, He T, Wang Q, Zhu GX, Xie M and Li XW. Carcass and meat quality traits of four commercial pig crossbreeds in China. Genetics and Molecular Research, 2012.1676-5680.

41. Bereskin B and Hetzer HO. Genetic and maternal effects on pig weights, growth and probe back fat in diallel crosses of high and low fat lines of swine. J. Anim. Sci, 1986. 63: 395-408. 